\title{
Digoxigenin-labeled probe for rabies virus nucleoprotein gene detection
}

\author{
Sonda marcada com digoxigenina para a detecção \\ do gene $\mathrm{N}$ do vírus da raiva
}

\author{
Pedro Carnieli Junior ${ }^{1}$, Armando Moraes Ventura ${ }^{2}$ \\ and Edison Luiz Durigon ${ }^{1,2}$
}

\begin{abstract}
A digoxigenin-labeled probe was produced from the Pasteur virus strain for the detection of the rabies virus $N$ gene. The probe hybridization was performed from amplified $N$ gene obtained by reverse transcription polymerase chain reaction and the results by RT-PCR and hybridization showed 100\% agreement. The hybridization, when carried out in products amplified by RT-PCR, increases the sensitivity of this technique even more and confers specificity to the diagnosis. The technique described in this work will be useful in rabies diagnosis laboratories, once the cost is compatible with traditional rabies diagnostic techniques.
\end{abstract}

Key-words: Rabies. $N$ Gene. Reverse transcription polymerase chain reaction. Probe. Hybridization.

\section{RESUMO}

Foi produzida uma sonda marcada com digoxigenina a partir da amostra Pasteur vírus para a detecção do gene $N$ do vírus da raiva. $A$ hibridação da sonda foi efetuada em amplificados do gene $N$ obtidos através de transcrição reversa-reação em cadeia da polimerase e os resultados do RT-PCR e hibridação foram 100\% concordantes. A hibridação, quando realizada em produtos amplificados por RT-PCR, aumenta ainda mais a sensibilidade desta técnica e confere especificidade ao diagnóstico. A técnica descrita neste artigo será útil em laboratórios de diagnóstico da raiva uma vez que tem custo compatível com as técnicas tradicionais para o diagnóstico da raiva.

Palavras-chaves: Raiva. Gene N. Transcrição reversa-reação em cadeia da polimerase. Sonda. Hibridação.

Rabies is a fatal cosmopolitan zoonosis of viral origin, which affects the central nervous system of mammals and is the $11^{\text {th }}$ cause of human death among infectious diseases ${ }^{19}$. The rabies virus belongs to the Lyssavirus genus of the Rhabdoviridae family ${ }^{15}$ and, up to the present, even though there are 7 existing genotypes worldwide, the only genotype isolated in Brazil is genotype $1^{10}$. Dogs and vampire bats are the main reservoirs of the virus in Brazil, but other nonhematophagous bats also act as virus reservoirs ${ }^{2}$.

Some studies with nucleoprotein gene $(\mathrm{N})$ in Brazil point to the existence of two main variants of the rabies virus (RABV): one found in the urban cycle, domestic animals and humans; and the other in the sylvatic cycle (hematophagous bats and cattle); and these two cycles overlap in many areas ${ }^{1011}$. However, in 2001 an epidemiological cycle of rabies in Northeastern Brazil was described $^{6}$, in which the marmoset (Callithrix jacchus) was responsible for the maintenance of the cycle.

Rabies diagnosis laboratories remain of utmost importance in countries where this disease still affects humans and domestic animals ${ }^{7}$. Laboratory techniques for diagnosis identify RABV in the central nervous system (CNS) with polyclonal antibodies or anti-nucleoprotein antibodies used in a direct fluorescent antibody test (FAT) and can be isolated by brain inoculation in mice (MIT), as recommended by the World Health Organization ${ }^{19}$ (WHO). Despite the fact that FAT is the gold-standard technique, this test can fail in decomposed samples or those with a small viral concentration ${ }^{8}$.

The genetic diagnosis of RABV is usually carried out by direct demonstration of the N gene by RT-PCR or indirectly, by performing hybridization after amplification by reverse

\footnotetext{
1. Institute Pasteur São Paulo, São Paulo, SP. 2. Department of Microbiology, Institute of Biomedical Sciences, University of São Paulo, São Paulo, SP, Brazil. Address to: Dr. Pedro Carnieli Junior. Instituto Pasteur de São Paulo. Av. Paulista 393, Cerqueira Cezar, 01311-000 São Paulo, SP, Brasil.

Tel: $55113288-0088$ r: 116, Fax: $55113284-4924$

e-mail: pecarniel@yahoo.com.br

Recebido para publicação em 9/11/2005

Aceito em 27/1/2006
} 
transcription polymerase chain reaction (RT-PCR $)^{13}$. RT-PCR in an ante mortem diagnosis, allows for early detection of the infection and post-exposure prophylaxis for people exposed to the virus sources 5 .

In general, DNA sequencing is used to carry out the genetic typing of RABV, frequently used in molecular epidemiology ${ }^{13}$. However, the utilization of a monoclonal-antibodies panel is of fundamental importance, since immunological detection is reliable and indicative of nonsilent genetic changes ${ }^{412}$.

RT-PCR amplification does not present sufficient specificity in highly degraded samples because unspecific band migrations can occur ${ }^{12}$. However, amplified products hybridized with probes, following Southern blot, characterizes specific and unspecific bands ${ }^{13}$. The simultaneous use of RT-PCR and probes avoid the risk of false-positive results in diagnoses by increasing sensitivity and specificity ${ }^{18}$.

The present study was aimed at the production of a digoxigenin-labeled probe for the detection of RABV $\mathrm{N}$ gene in a safe and economic manner and to add one more home-made technique to the set of ready-to-use techniques for rabies diagnosis.

\section{MATERIAL AND METHODS}

Samples. Fourteen clinical samples of Brain Tissue from the Pasteur Institute, SP, Brazil and the Veterinary Medicine School of São Paulo University, Brazil, all positive by FAT and MIT, were included in this study. The Pasteur virus strain (PV) was used, as standard positive control, while a rabies negative CNS sample, as tested by FAT and MIT, as well as ultra-pure water, were included as a negative control. Each step, RNA extraction, RT-PCR, electrophoresis and probe assays, was carried out in separate rooms with exclusive materials and equipments.

Primers. The primers for the rabies virus $\mathrm{N}$ gene were designed from the nucleotide sequence of the PV strain, obtained from the GenBank (accession number M13215). Primers for the $\mathrm{N}$ gene were named N1 5' ATG GAT GCC GAC AAG ATT 3' (sense) and N2 5' TTA TGA GTC ACT CGA ATA 3’ (anti-sense) (positions 71-89 and 1403-1421 of the PV strain).

RNA Extraction, Reverse Transcription and PCR. Total RNA from the clinical samples and the PV standard sample was extracted with Trizol (Invitrogen ${ }^{\mathrm{TM}}$ ) according to the manufacturer's instructions. Extracted RNA was reverse transcribed in a mix containing 50pMoles of primers N1/N2, $50 \mathrm{mM}$ Tris- $\mathrm{HCl}, 75 \mathrm{mM} \mathrm{KCl}, 3 \mathrm{mM} \mathrm{MgCl}_{2}, 10 \mathrm{mM}$ DTT, $200 \mathrm{U}$ Reverse Transcriptase (Superscript ${ }^{\mathrm{TM}}$ II - Invitrogen $^{\mathrm{TM}}$ ), 20U Rnase inhibitor, $1.5 \mathrm{mM}$ dNTP in a final volume of $40 \mu \mathrm{L}$. The mix was incubated at $42^{\circ} \mathrm{C}$ for 1 hour. The cDNA synthesized was amplified with the same primers by PCR in a mix containing $10 \mu \mathrm{L}$ of cDNA, $20 \mathrm{mM}$ Tris $\mathrm{HCl}, 50 \mathrm{mM} \mathrm{KCl}, 1.5 \mathrm{mM} \mathrm{MgCl}_{2}$, 50pMoles of each primer (N1/N2), 2.5U Taq DNA Polymerase (Invitrogen $^{\mathrm{TM}}$ ) and $200 \mathrm{mM}$ dNTP in a final volume of $100 \mu \mathrm{L}$. Amplification conditions consisted of $5 \mathrm{~min}$ at $94^{\circ} \mathrm{C}$, followed by
35 cycles of PCR $\left(94^{\circ} \mathrm{C}\right.$ for $45 \mathrm{sec}, 55^{\circ} \mathrm{C}$ for $45 \mathrm{sec}, 72^{\circ} \mathrm{C}$ for $1 \mathrm{~min}$ and $30 \mathrm{sec}$ ) and $7 \mathrm{~min}$ at $72^{\circ} \mathrm{C}$.

Construction of the probe and labeling with digoxygenin. The "DIG DNA Labeling Kit" system was used (Boehringer Mannheim) for $\mathrm{N}$ probe production. The $\mathrm{N}$ gene was obtained by RT-PCR amplification of the PV sample as described above. Next, the amplified band was excised from the agarose gel, dialyzed in TBE $0.5 \%$ and electroeluted under $100 \mathrm{~V}$ for 1 hour and purified with phenol/ chloroform, as described by Sambrook et $\mathrm{al}^{8}$, then re-suspended in $20 \mu \mathrm{L}$ TE. Two $\mu \mathrm{L}$ of this purified product were diluted in $15 \mu \mathrm{L}$ of ultra-pure water and boiled at $100^{\circ} \mathrm{C}$ for 10 minutes and then cooled in dry-ice with ethanol. After thawing, the product described above was added to $2 \mu \mathrm{L}$ of hexanucleotides (dUTP), $2 \mu \mathrm{L}$ of dNTP-DIG, $1 \mu \mathrm{L}$ of Klenow enzyme, in order to generate a pool of random fragments complementary to the $\mathrm{N}$ gene. After 12 hours at $37^{\circ} \mathrm{C}$, the reaction was diluted in $150 \mu \mathrm{L}$ of TE, added to a spin column with positive charge and centrifuged at $2000 \mathrm{~g}$. Finally, the product (DNA labeled with digoxigenin) was diluted within $30 \mu \mathrm{L}$ of ultra-pure water.

Southern-blot hibridization and detection by the Immunechemiluminescence. After electrophoresis of the RT-PCR products derived from the clinical samples, denaturation of the products was realized by keeping the gel under denaturant buffer $(0.5 \mathrm{~N} \mathrm{NaOH} ; 1.5 \mathrm{M} \mathrm{NaCI}$; ) for 60 minutes, neutralizing it in neutralizing buffer $(0.5 \mathrm{M}$ Tris- $\mathrm{HCl}$; 1.5 M NaCI; $\mathrm{pH} 7.5)$ for 30 minutes and transferring it for 60 minutes to a nylon membrane using a Vaccum Blotter (BioRAD, Melville, NY, USA), with $127 \mathrm{mmHg}$ for $90 \mathrm{~min}$ in $20 \mathrm{X}$ SSC (3M NaCI; 0.3M citrate of sodium; pH 7.0) buffer. After two immobilization cycles of the product under UV radiation in Ultraviolet Cross Linker (Amersham International plc, Littie Chelfont, Bucks, England, UK), the membrane was prehybridized in buffer [ 5 x SSC; $0.02 \%$ (w/v) SDS; $1 \%$ (w/v) of blocked reagent (Boehringer Mannheim)] for 1 hour, at $60^{\circ} \mathrm{C}$, and hybridized utilizing the previous buffer added to the digoxigenin-marked probe to a final concentration of 10 $\mathrm{pmol} / \mathrm{mL}$ in a Hybridization Oven/Shaker System (Amersham, International), in roller tubes for 6 hours at $60^{\circ} \mathrm{C}$, as a factor of stringency. Next, the membrane was kept in blocking solution [ (100mMTris-HCI; 150m M NaCI; 2\% (w/v) of reagent of blocked; $\mathrm{pH}$ 7.0)] for 1 hour and replaced by the washing buffer (100m M Tris-HCI; $150 \mathrm{~m} \mathrm{M} \mathrm{NaCI)} \mathrm{for} 2$ minutes. Then, the reaction was added to blocking solution with anti-digoxygenin antibody conjugated with alkalinephosphatase (antidigoxigenin-AP Fab fragments- Boehringer Mannhelm), at $250 \mathrm{mU} / \mathrm{mL}$, for 30 minutes, followed by two 15 minutes washes in washing buffer and, finally, washed in equilibrium buffer (100mM Tris-HCI; $100 \mathrm{mM} \mathrm{NaCI}$; 50mM $\left.\mathrm{MgCl}_{2} ; \mathrm{pH} 9,5\right)$ for 5 minutes. Detection was carried out by adding 1mL of LUMI-PHOS 530 (Boehringer Mannhelm) to the membrane inserted between acetate sheets, incubated at $37^{\circ} \mathrm{C}$, for 30 minutes and exposed to a X-OMat AR film (Eastman Kodak CO., Rochester) for a variable period of 1 to 4 minutes and developed in a dark room. 


\section{RESULTS}

All samples diagnosed as positive for rabies virus by FAT and MIT were confirmed as positive by RT-PCR and with the N probe. Also, the samples negative by FAT and MIT were also negative by RT-PCR and with the N probe (Table 1 and Figure 1).

Table 1- Results of studied samples by FAT, MIT, RT-PCR and hybridization with $\mathbf{N}$ Probe according to species.

\begin{tabular}{lccccc}
\hline Sample & Species & FAT & MIT & RT-PCR & Probe N \\
\hline 1 & equine & + & + & + & + \\
2 & dog & + & + & + & + \\
3 & vampire bat & + & + & + & + \\
4 & vampire bat & + & + & + & + \\
5 & vampire bat & + & + & + & + \\
6 & vampire bat & + & + & + & + \\
7 & bovine & + & + & + & + \\
8 & bovine & + & + & + & + \\
9 & bovine & + & + & + & + \\
10 & bovine & + & + & + & + \\
11 & dog & - & - & - & - \\
12 & dog & - & - & - & - \\
13 & ovine & - & - & - & - \\
14 & bovine & - & - & - & - \\
\hline
\end{tabular}

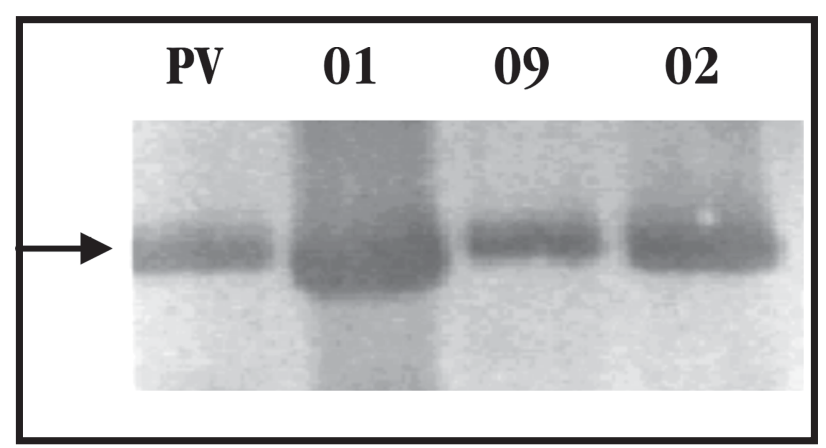

Figure 1- Detection of $N$ probe in sample $P V$ and in the clinical samples 01,09 and 02.

\section{DISCUSSION}

The production of the probe presented in this work aimed to propose an alternative approach for the genetic diagnosis of RABV by detection of the $\mathrm{N}$ gene. RABV must be detected in a fast and safe manner and its diagnosis needs to be constantly improved. The direct fluorescent antibody test (FAT), established by the WHO, is quick, simple, sensitive and has a reasonable cost. However, in some situations, this technique is not efficient, as in decomposed or formalin-fixed samples ${ }^{17}$. The WHO recommends the use of a complementary test, such as brain inoculation in mice (MIT), which can take up to 25 days to produce a conclusive result, has a high financial cost and is not reliable in decomposed samples ${ }^{19}$.

In situations where the isolation of the virus is impossible, as mentioned above, the use of RT-PCR is of primary importance 9 . The RT-PCR technique offers sensitivity and a reduced time for result acquisition at a cost that is compatible with other methodologies, but offers risks regarding falsepositive results due to the potential cross-contamination of samples ${ }^{16}$. Hybridization, when carried out in products amplified by RT-PCR, increases the sensitivity of this technique even more and confers specificity to the diagnosis ${ }^{13}$.

The ability to detect rabies virus in clinical samples can be increased with the use of a second amplification step, using the technique of Nested PCR, but this procedure increases the risk of false-positive results due to DNA contamination. One advantageous aspect of hybridization is a lower probability of laboratory contamination with DNA, and its sensitivity is comparable to Nested-PCR ${ }^{8}$.

Despite the fact that molecular techniques are routinely used, they have been restricted to special diagnosis situations and to laboratories able to carry out such techniques. In these cases, the probe described here targeted to the $\mathrm{N}$ gene, might be useful to increase the accuracy of the results obtained with RT-PCR. Yet, home-made probes are much more economic when compared to commercial probes, which makes them a viable alternative for laboratories intending to carry out rabies diagnosis and rabies virus diversity based on nucleic acids. Finally, nonradioactive probes not only have a longer half life but also are safer, since they avoid the manipulation of radioactive isotopes.

Probe sequencing was not performed in the present research due to the presence of various molecules of digoxigenin in the $\mathrm{N}$ probe pool, which was randomly produced, according to the DIG DNA Labeling KIT methodology, and could inhibit sequencing reactions. Furthermore, as described in Material and Methods, the probe was produced as a pool of random fragments with multiple sizes and sequences primed with hexanucleotides (dUTP), a process that imposes technical difficulties in the determination of these sequences.

Nonetheless, as the probe was generated with the whole $\mathrm{N}$ gene amplified by PCR as a template, it could be argued that only $\mathrm{N}$ gene specific segments were obtained.

Besides, the random characteristics of the pool of segments in the $\mathrm{N}$ probe enhance the sensitivity of RABV detection, since variants of the virus with small nucleotide differences in an $\mathrm{N}$ gene can be detected.

The 14 field strains of rabies virus tested by the digoxigeninlabeled probe described in this article, demonstrate that such a probe may be used on a larger number of field samples after RT-PCR, in order to increase the specificity of the results in a faster, easier and more economic manner when compared to DNA sequencing, while also avoiding chromatogram misinterpretations due to sequencing errors.

The $\mathrm{N}$ gene is the most conserved region on the $\mathrm{RABV}$ genome and, for this reason, is the target for diagnosis ${ }^{1}$. In this research, the PV strain was used for production of the N probe, since this is a widely used vaccine strain and, theoretically, possesses antigenic and genetic characteristics similar to a large number of populations of circulating rabies virus. The results presented herein show that the probe produced allowed for the detection of the $\mathrm{N}$ gene in rabies-positive samples from the two most important populations of rabies reservoirs: dogs and vampire bats. 
In conclusion, the $\mathrm{N}$ probe produced in the research described in this article from the full length of the amplified $\mathrm{N}$ gene of RABV has a high capacity to detect RABV in clinical samples. The production of probes for the detection of the $\mathrm{N}$ gene reinforces the importance of the development of molecular methods for the diagnosis of RABV.

\section{REFERENCES}

1. Badrane HA, Tordo N. Host switching in lyssavirus history from chiroptera to the carnivora orders. Journal of Clinical Virology 75: 8096-8104, 2001.

2. Belotto A, Leanes LF, Schneider MC, Tamayo H, Correa E. Overview of rabies in the Americas. Virus Research 111: 5-12, 2005.

3. Carnieli Jr P, Brandão EP, Castilho JG, Bueno CR, Carrieri ML, Macedo CI, Oliveira RN, Zanetti CR, Kotait I. Phylogeny of a rabies virus identified in a cat closely related to vampire-bat rabies base don the nucleoprotein gene. Virus Reviews and Research 10: 38-44, 2005.

4. Cisterna D, Bonaventura R, Caillou S, Pozo 0, Andreau ML, Fontana LD, Echegoyen C, De Mattos CC, De Mattos CA, Russo S, Novaro L, Elberger D, Freire MC. Antigenic and molecular characterization of rabies virus in Argentina. Virus Research 109: 139-147, 2005.

5. Crepin P, Audry L, Rotivel Y, Gacoin A, Caroff C, Bourhy H. Intravitan diagnosis of human rabies by PCR using saliva and cerebrospinal fluid. European Journal of Clinical Microbiology 36: 1117-1121, 1998.

6. Favoretto SR, De Mattos CC, Morais NB, Alves Araujo FA, De Mattos CA. Rabies in marmosets (Callithrix jacchus), Ceará, Brazil. Emerging Infectious Diseases 7: 1062-1065, 2001.

7. Fundação Nacional de Saúde. Guia de vigilância epidemiológica. Ministério da Saúde, 5ª edição, Brasília, volume 2, p. 671-704, 2002.

8. Heaton PR, Johnstone P, Mcelhinney LL, Cowley R, O'sullivan E, Whitby JE. Heminested PCR assay for detection of six genotypes of rabies and rabiesrelated viruses. European Journal of Clinical Microbiology 35: 2762-2766, 1997.
9. Instituto Pasteur. Secretaria de Estado da Saúde de São Paulo-Informes Técnicos Institucionais. Case report of post-exhumation human rabies in the city of Sao Paulo. Revista de Saúde Pública 38:741-742, 2004.

10. Ito M, Arai TY, Itou T, Sakai T, Ito HF, Takasaki T, Kuranet I. Genetic characterization and geographic distribution of rabies virus isolates in Brazil: identification of two reservoirs, dogs and vampire bats. Virology 284: 214-222, 2001.

11. Ito M, Itou T, Shoji Y, Sakai T, Ito HF, Arai TY, Takasaki T, Kurane I. Discrimination between dog-related and vampire bat-related rabies viruses in Brazil by strain-specific reverse transcriptase-polymerase chain reaction and restriction fragment length polymorphism analysis. Journal of Clinical Virology 26: 317-330, 2003.

12. Nadin-Davis SA, Casey GA, Wandeler AL. Identification of regional variants of the rabies virus within the Canadian province of Ontario. The Journal of General Virology 74: 829-837, 1993.

13. Sacramento D, Bourhy H, Tordo N. PCR technique as an alternative method for diagnosis and molecular epidemiology of rabies virus. Molecular and Cellular Probes 5: 229-240, 1991.

14. Sambrook J, Fritsch EF, Maniatis T. Molecular cloning: a Laboratory Manual, $2^{\text {nd }}$ edition, Cold Spring Harbor Laboratory, New York, 1989.

15. Van Regenmortel MHV, Fauquet CM, Bishop DHL, Carstens EB, Estes MK, Lemon SM, Maniloff J, Mayo MA, McGeoch DJ, Pringle CR, Wickner RB. Virus Taxonomy: the classification and nomenclature of viruses. The Seventh Report of the International Committee on Taxonomy of Viruses. Academic Press, San Diego, 2000.

16. Wakeley PR, Johnson N, McElhinney LM, Marston D, Sawyer J, Fooks AR. Development of a real-time, TaqMan reverse transcription-PCR assay for detection and differentiation of lyssavirus genotypes 1, 5, and 6. Jounal of Clinical Microbiology 43: 2786-2792, 2005.

17. Webster WA, Casey GA. Virus isolation in neuroblastoma cell culture. In: Meslin FX, Kaplan MM, Koprowski H (eds) Laboratory techniques in rabies. World Health Organization, $4^{\text {th }}$ edition, Geneva, p. 78-95, 1996.

18. Whitby J, Heaton PR, Whitby HE, O'Sullivan E, Johnstone P. Rapid detection of rabies and rabies-related viruses by RT-PCR and enzyme-linked immunosorbent assay. Journal of Virological Methods 69: 63-72, 1997.

19. World Health Organization. World Survey of Rabies No. 34 for the Year 1998. World Health Organization, Geneva, 2000. 